\title{
Gene Variants that Predispose to Achilles Tendon Injuries: An Update on Recent Advances
}

\author{
Stuart M. Raleigh ${ }^{1}$ and Malcolm Collins ${ }^{2}$ \\ ${ }^{1}$ School of Health, Division of Health and Life Sciences, \\ University of Northampton, Northampton \\ ${ }^{2} \mathrm{MRC/UCT}$ Research Unit for Exercise Science and \\ Sports Medicine of the South African Medical Research \\ Council and the Department of Human Biology, \\ University of Cape Town, Cape Town \\ ${ }^{1} U K$ \\ ${ }^{2}$ South Africa
}

\section{Introduction}

There are a number of injuries that affect the Achilles tendon and surrounding tissues. Injuries that affect the surrounding tissues include bursitis and paritendonitis, while Achilles tendinopathy and complete or partial ruptures affect the tendon tissue itself (Puddu, 1976). Although injuries to the Achilles tendon are common as a result of participation in physical activities, Achilles tendon injuries can also occur in sedentary individuals (Young et al., 2005). Although the biological and molecular mechanisms responsible for Achilles tendon injuries are largely unknown, both intrinsic and extrinsic risk factors have nevertheless been implicated in the aetiology of these conditions (Figure 1) (Meeuwisse, 1994; Riley, 2004; September et al., 2006). Genetic susceptibility, which will be the focus of this review, has more recently been included as one of the intrinsic risk factors for chronic Achilles tendinopathy. As illustrated in figure 1, many of the intrinsic risk factors associated with Achilles tendinopathy are in their own right complex phenotypes determined by both genetic and environmental factors. Flexibility (Battie et al., 2008), biological age (Newman et al., 2010), muscle strength (Stewart et al., 2006), weight (Herrera et al., 2010) are all determined by genetic and environmental factors, the development of the male sex on the other hand is determined genetically (Kousta et al., 2010).

A brief summary of the macromolecular structure of tendons is required to understand and review our current knowledge of the genetic basis of Achilles tendon injuries. Tendons have a highly ordered hierarchical structure made up of tightly packed bundles of fibrils consisting predominately of type I collagen fibres (60\% of the dry mass of tendons) (Silver et al., 2003). Other quantitively minor collagens, such as type III, V, XIV and XVI collagens form heterotypic fibrils with type I collagen or are associated with the surface of the fibrils 


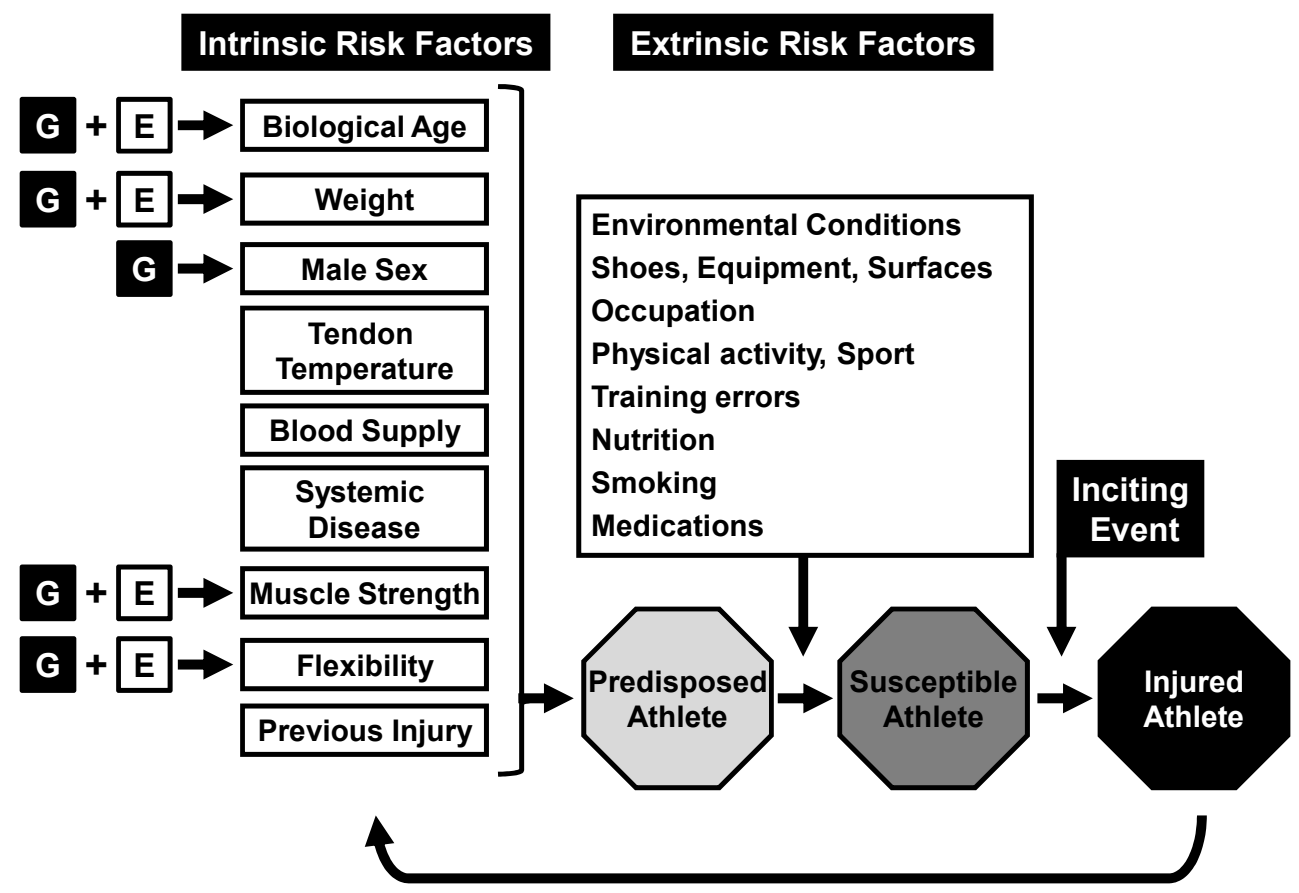

Fig. 1. A diagram illustrating the role of intrinsic and extrinsic risk factors, as well as, the inciting event in the aetiology of Achilles tendon injuries (Meeuwisse, 1994; Riley, 2004; September et al., 2006). Many of the individual intrinsic risk factors are multifactorial phenotypes, which are determined by, to a lesser or greater extent, both genetic (nature, $G$ ) and environmental (nurture, E) factors. For acute Achilles tendon injuries the inciting event will be the macrotraumatic event that cause the injury, while the inciting event for a chronic injury will be the point in time when the volume of accumulated micotraumatic damage to the tissue becomes symptomatic. The arrow from the injured Athlete back to list of intrinsic risk factors indicated that once recovered the previous injury predisposes the athlete for additional injuries.

(Canty \& Kadler, 2002). These additional collagens play essential roles in tendon biology. Various glycoproteins and proteoglycans, such as tenascin C, decorin, biglycan, aggrecan, lumican, fibromodulin and others, are also important structural components of tendons (Kannus, 2000; Silver, 2003). The expression of many of these protein components has been shown to be altered during tendon injury (Ireland et al., 2001; Alfredson et al., 2003). Many collagen types, cell adhesion molecules, proteoglycans and, matrix metalloproteainases (MMPs), ADAMTS (A Disintegrin And Metalloproteinase with Thrombospondin Motifs - a family of peptidases), tissue inhibitors of metalloproteinases (TIMPS), cell receptors, cytokines and other signalling molecules are either up- or down-regulated in degenerative Achilles tendons (Ireland et al., 2001). 


\section{Genetic association studies with relevance to injury of the Achilles tendon}

Genetic association studies are designed to investigate whether a particular allele or genotype significantly co-segregates with a particular disease trait (Lewis, 2002). Since 2005 such studies have successfully been employed to establish the identity of risk variants for Achilles tendon injuries (Collins \& Raleigh, 2009). To date, genetic association studies that are relevant to Achilles tendon injuries have been based on the case-control, candidate gene approach (Collins \& Raleigh, 2009). These studies rely on the accurate ascertainment of a clinically distinct phenotype which, as discussed above, can be a challenge for pathology or injury related to the Achilles tendon. In addition to the quality of the phenotypic data the design of a genetic association study must take into account potential confounding factors such as population stratification (Lewis, 2002). For multifactorial conditions such as Achilles tendon injuries other intrinsic factors, such as, amongst others, age and sex, as well as, extrinsic factors, such as type of sporting codes and duration of exposure to high risk activity, should also be considered when selecting cases and controls. The severity of the injury should also be considered when defining the inclusion and exclusion criteria. With respect to chronic Achilles tendinopathy, the following inclusion criteria have previously be used to define a severe phenotype (i) symptoms greater than 6 months, (ii) bilateral Achilles tendinopathy, (iii) multi-injuries, (iv) other tendon injuries and/or (v) early age of initial onset of symptoms (Mokone et al. 2005). The selection of appropriately matched controls is as important as the selection of the cases.

For the candidate gene approach, investigators select variants that are plausible candidates for a role in the pathology and determine whether an allele or genotype appears at a significantly greater frequency in cases compared to a matched control group (Cordell \&, Clayton, 2011). The genome wide approach (GWA) tends to use large numbers of cases and controls that are genotyped for many thousands of tagged single nucleotide polymorphisms (SNPs) (Hosking et al, 2011). Investigators predominantly use Affeymetrix or Illumina technology for these investigations but genome wide significance is generally set within the order of $\mathrm{P}<0.0000001$ to account for multiple testing (Grant \& Hakonarson, 2008). Although GWA studies have clearly advanced our understanding of a number of complex diseases (Grant \& Hakonarson, 2008) the technology has not yet been utilised in relation to gene variants that predispose to injuries of the Achilles tendon. In the following section we update our knowledge of gene variants that have been associated with Achilles tendon injuries. Our main focus of this article will be to update the reader on the most recent advances (from 2010 onwards) in the field. However, although we will begin with a brief review of some of the studies that prompted investigators to the search for specific gene variants that could influence the risk of Achilles tendon injuries (section 3) the reader is also advised to consult earlier reviews (September et al. 2006; 2007; Magra and Maffulli, 2007, Collins \& Raleigh, 2009).

\section{Initial investigations}

In 1989 Jozsa and co-workers conducted a retrospective study on the frequency of different blood groups in a Hungarian population that had suffered from tendon ruptures (Jozsa et al, 1989). They found an abundance (53\%) of blood group $\mathrm{O}$ in their cohort compared to $31 \%$ of the control sample. The abundance of group $\mathrm{O}$ was even higher $(69 \%)$ in individuals who had sustained a re-rupture (Jozsa et al, 1989). Subsequent studies by Kujala and colleagues 
(Kujala et al, 1992) and Kannus and Natri (Kannus \& Natri, 1997 as cited by September, 2007) have documented associations between Achilles tendon rupture and blood group distribution. Interestingly, the relationship between blood group distribution and risk of Achilles tendon rupture was not observed in subsequent work involving 215 Achilles patients recruited in a Finnish cohort (Leppilahti et al, 1996), 78 patients in a Scottish based cohort (Maffulli et al, 2000) and in a small South African based study involving 75 rupture cases and 131 controls (Mokone, 2006 as cited by September 2007).

Despite the contrasting findings, Mokone and colleagues (Mokone et al, 2005) speculated that variants residing in genes encoding tendon structural or regulatory proteins, that were proximal to the $\mathrm{ABO}$ chromosome locus (on 9q34) might be candidates for association with Achilles tendon injuries. With this in mind, Mokone and co-workers conducted the first case-control, genetic association study using the candidate gene approach for risk variants relating to Achilles tendon injury. Using a sample of 114 Achilles tendon sufferers and 127 matched controls they established that a dinucleotide repeat polymorphism within the tenascin-C gene (TNC), a gene encoding an important enzyme that regulates cell matrix interactions (Jones \& Jones, 2000) was associated with Achilles tendon injuries (Mokone et al, 2005). Interestingly the study demonstrated that the odds ratios, a quantitative estimate of disease risk based on the carrier of an allele or genotype in cases divided by controls (Lewis et al, 2002), was found to be high. Indeed possession of the 12 and 14 repeat alleles cosegregated with a six fold increase in injury risk (Mokone et al, 2005).

Attention was then focused on genomic variation within the gene that encodes the pro$\mathrm{a} 1(\mathrm{~V})$ chain of collagen type $\mathrm{V}$ (COL5A1) as a possible susceptibility locus for Achilles tendon injuries. Specifically, using a South African based cohort two polymorphisms were selected within the COL5A1 gene and one of them (rs12722) was found to significantly associate with chronic Achilles tendinopathy (Mokone et al, 2006). The DpnII restriction fragment length polymorphism also investigated by this group was not associated with injury or tendinopathy of the Achilles tendon (Mokone et al, 2006). Both these polymorphic markers are located within the $3^{\prime}$-untranslated region (UTR) of the COL5A1 gene (September et al, 2009). Since 2006 confirmation of the association of the rs12722 polymorphism in Achilles tendon pathology has been documented in an Australian population, both as a single marker, and as an inferred haplotype in combination with the $C$ allele of the rs3196378 polymorphism (September et al, 2009). In addition to COL5A1, three variants within the MMP3 gene were also found to associate with Achilles tendinopathy in South Africans (Raleigh et al, 2009). Interestingly previous (Alfredson et al, 2003, Ireland et al, 2001) and more recent data (de Mos et al, 2009, Jelinsky et al, 2011) have shown that MMP3 expression levels are significantly repressed in tissue obtained from Achilles tendinopathic material when compared to controls.

\section{Contemporary investigations}

Although a diverse group of candidate genes for Achilles tendon injuries were suggested in 2006 (September et al, 2006) association studies up to and including 2010 have been limited to variants within genes for proteins involved in the structural or regulatory integrity of tendon or the extracellular matrix (Like COL5A1 and MMP3 respectively). To broaden the spectrum of possible candidates, Posthumus and co-workers speculated that members of the transforming growth factor- $\beta$ (TGF- $\beta$ ) family might influence 
predisposition to the risk of these injuries (Posthumus et al, 2010). They chose this group as logical candidates based on the biochemical functions that TGF- $\beta$ transcripts had in relation to Achilles tendon function. For example, it was known that TGF- $\beta$ transfected into healing rabbit Achilles tendon led to enhanced mechanical strength of the tendon due to the regulation of collagen turnover and cross link formation (Hou et al, 2006). However, the functional promoter variant rs1800469 of the TGF- $\beta$ gene was not found to cosegregate with Achilles tendon pathology in both South African and Australian Caucasian cohorts (Posthumus et al, 2010).

The same investigators then examined the possible role of another variant (rs143383) within a second member of the TGF- $\beta$ family, namely the growth differentiation factor 5 (GDF-5) gene, for association with Achilles tendon injury. They found that carriage of the TT genotype at the rs143383 locus was associated with Achilles tendon pathology in Australian cases and when the data were combined for both cohorts of Australian and South Africans (Posthumus et al, 2010). At present a mechanism for how the rs143383 variant exerts its influence on risk of Achilles tendon injury is unknown. However, it is interesting to note that the $\mathrm{T}$ allele of this variant has been reported to repress the expression of GDF-5 in tissue obtained from osteoarthritis patients (Egli et al, 2009). Furthermore, genotype at this locus (possession of either the $\mathrm{T}$ or $\mathrm{C}$ allele) has also been shown to govern the binding of the deformed epidermal autoregulatory factor 1 (DEAF-1) transcription factor which may have a role in osteoarthritis susceptibility (Egli et al, 2009). Accordingly, genetic variants within the DEAF-1 gene might also be candidates for Achilles tendon injuries. It is also noteworthy that the rs143383 variant has been associated with a range of other musculoskeletal pathologies. For example the rs143383 variant has been shown to be a susceptibility locus for osteoarthritis of the knee (Valdes et al, 2011) and a recent large-scale study in European cohorts has documented that the T allele of rs143383 was associated with lumber disc degeneration in women (F.M Williams et al, 2011).

So far we have seen how population-based association studies have enhanced our understanding of the genetic risk factors that can predispose to Achilles tendon injuries. A summary of this data (including only significant associations discussed in sections 3 and 4) is shown in Table 1.

Although studies up to 2010 have focused on single genetic loci or haplotypes that can predispose to Achilles tendon injuries a recent study has utilised a pathway-based model to study predisposing genotypes for Achilles tendon pathology (September et al, 2011). Specifically, the investigators wanted to establish whether allelic variants within a selction of inflammatory genes (interleukin- $1 \beta$, interleukin- 6 and interleukin- 1 receptor antagonist), that are differentially expressed in tendinopathy (September et al, In Press), were associated with the problem when combined with the COL5A1 rs12722 variant. Interestingly, they discovered that as single loci none of the variants associated with Achilles tendinopathy. However, in combination, the five variants tested, along with the COL5A1 variant, were significantly associated $(\mathrm{p}<0.005)$ with Achilles tendinopathy (September et al, 2011). This work demonstrates that polygenic profiling of a complex phenotype like Achilles tendinopathy maybe a superior strategy to use, compared to the single candidate approach, when it comes to understanding the intricate involvement of numerous variants that increase the risk of Achilles tendon problems (September et al, 2011). 


\begin{tabular}{|c|c|c|c|}
\hline Gene & Variant/population & Notes & Reference \\
\hline Tenascin C (TNC) & $\begin{array}{l}\text { GT repeat variant within } \\
\text { intron } 7 . \\
\text { South African Caucasian } \\
(\mathrm{N}=241) .\end{array}$ & $\begin{array}{l}12 \text { and } 14 \text { GT repeat } \\
\text { variants associated } \\
\text { with Achilles tendon } \\
\text { injuries. Both allelic } \\
\text { and genotypic } \\
\text { associations were } \\
\text { observed. }\end{array}$ & $\begin{array}{l}\text { Mokone et } \\
a l, 2005\end{array}$ \\
\hline $\begin{array}{l}\text { Type V Collagen, a } 1 \\
\text { chain, (COL5A1) }\end{array}$ & $\begin{array}{l}\text { rs12722 } \\
\text { South African Caucasian } \\
(\mathrm{N}=240) \text {. }\end{array}$ & $\begin{array}{l}\text { A2 allele } \\
\text { overrepresented in } \\
\text { control subjects } \\
\text { inferring a protective } \\
\text { role for this allele. }\end{array}$ & $\begin{array}{l}\text { Mokone et } \\
\text { al, } 2006\end{array}$ \\
\hline $\begin{array}{l}\text { Type V Collagen, a } 1 \\
\text { chain, (COL5A1) }\end{array}$ & $\begin{array}{l}\text { rs12722 and rs3196378 } \\
\text { Australian Caucasian } \\
(\mathrm{N}=295) .\end{array}$ & $\begin{array}{l}\text { The CC genotype of } \\
\text { rs12722 } \\
\text { underrepresented in } \\
\text { Achilles } \\
\text { tendinopathy The } \\
\text { rs12722 and } \\
\text { rs3196378 variant } \\
\text { associated with } \\
\text { tendinopathy as an } \\
\text { inferred haplotype }\end{array}$ & $\begin{array}{l}\text { September et } \\
a l, 2009\end{array}$ \\
\hline $\begin{array}{l}\text { Matrix } \\
\text { metalloproteinase } 3 \\
(M M P 3)\end{array}$ & $\begin{array}{l}\text { rs679620, rs591058 and } \\
\text { rs650108 } \\
\text { South African Caucasian } \\
(\mathrm{N}=212) .\end{array}$ & $\begin{array}{l}\text { The GG genotype of } \\
\text { rs679620 associated } \\
\text { with Achilles } \\
\text { tendinopathy. The } \\
\text { rs679620, rs591058 } \\
\text { and rs650108 variants } \\
\text { also associated as an } \\
\text { inferred haplotype }\end{array}$ & $\begin{array}{l}\text { Raleigh et al, } \\
2009\end{array}$ \\
\hline $\begin{array}{l}\text { Growth differentiation } \\
\text { factor } 5 \text { (GDF-5) }\end{array}$ & $\begin{array}{l}\text { rs143383 } \\
\text { Australian and Australian } \\
\text { in combination with South } \\
\text { African Caucasian }(\mathrm{N}=406) \text {. }\end{array}$ & $\begin{array}{l}\text { The TT genotype of } \\
\text { rs143383 } \\
\text { overrepresented in } \\
\text { Australian and } \\
\text { combined Australian } \\
\text { and South African }\end{array}$ & $\begin{array}{l}\text { Posthumus } \\
\text { et al, } 2010\end{array}$ \\
\hline
\end{tabular}

Table 1. Genetic variants associated with Achilles tendon pathology in humans. Entries summarise the results of separately published studies investigating a single variant or a haplotype. Information on individual variants can be found by databases hosted by the NCB1 available at http://www.ncbi.nlm.nih.gov/projects/SNP/. 


\subsection{The COL5A1 3'-UTR is functional and associated with other exercise-related phenotypes}

Although a genetic association of a sequence variant (rs12722) within the COL5A1 3'-UTR has previously been reported for chronic Achilles tendinopathy (Mokone et al, 2006; September et al, 2009) in two independent populations, the biological function, if any, of the COL5A1 3'-UTR was initially unknown. The 3'-UTR of many eukaryotic protein-coding genes contains regulatory elements, such as miRNA binding sites, involved in the etiology of many diseases (Mazumder et al., 2003). In addition variant rs12722 within the COL5A1 3'UTR is in close proximity with two polymorphic putative miRNA binding sites within the COL5A1 3'-UTR (September et al, 2009). Due to the structural similarities of tendon and ligaments at the molecular level, the association of the COL5A1 rs12722 variant with another musculoskeletal soft tissue injury, namely anterior cruciate ligament (ACL) rupture, was investigated. Within females the, CC genotype of SNP rs12722 was significantly underrepresented among the cases (Posthumus et al, 2009). Although it well document that females are at greater risk for ACL ruptures, the reason for this sex-specific association remains unknown.

Both an increase and decrease in joint range of motion (ROM) is a modifiable risk factor for Achilles tendon injuries (Brown et al., 2011a). In addition, COL5A1 haploinsufficiency is a common molecular mechanism causing the classic form of Elhers Danlos Syndrome (EDS), which presents with amongst other symptoms joint hypermobility (Malfait et al., 2010). Brown et al (2011a) recently reported that the COL5A1 CC genotype 'protected' individuals against an age-related decline in ROM measurements. Finally the 'less flexible' COL5A1 TT genotype has been shown to be significantly associated with improved endurance running performance (Posthumus et al, 2011; Brown et al, 2011b). This finding is in agreement with the published inverse relationship between musculotendineous stiffness and running economy (Arampatzis et al, 2006; Dumke et al, 2010; Fletcher et al, 2010).

As reviewed above the COL5A1 rs12722 SNP has been associated with Achilles tendinopathy and other exercise-related phenotypes. This single nucleotide DNA sequence variation is not necessarily the cause of these phenotypes. Genetic association studies do not prove cause and effect but highlight genetic regions, proteins or biological pathways that should be further investigated using other biological techniques. This rs12722 SNP is however probably tightly linked to the as yet unknown phenotype-causing polymorphism(s) either within the $3^{\prime}$-UTR of the COL5A1 gene, other regions of COL5A1 or a neighboring gene. The results do however indicate that SNP rs12722 is a representative genetic marker for the genetic region (locus) within or surrounding the COL5A1 gene, which may potentially cause these reported phenotypes.

To test whether the COL5A1 3'-UTR was functional, Laguette et al (2011) cloned the COL5A1 3'-UTR from participants with chronic Achilles tendinopathy or asympomatic controls upstream of a firefly-luciferase reporter gene and transiently transfected the clones into HT1080 cells. They reported an overall increase in COL5A1 mRNA stability in the tendinopathic phenotype and identified two major functional forms of the COL5A1 3'-UTR. The one functional form corresponded to the wild type sequence, includes the $C$ allele of SNP rs12722, and was identified in most of the clones generated from asymptomatic controls. The second functional form, on the other hand, included the T allele of SNP rs12722 and was predominantly identified in the Achilles tendinopathic patients. An overall 
increase in mRNA stability was asscoiated with the second functional form of the COL5A1 3'-UTR, which was cloned from participants with chronic Achilles tendinopathy (Laguette et al, 2011).

The COL5A1 gene encodes the a1 chain of type V. Although present in much smaller amounts than type I collagen, type $\mathrm{V}$ collagen plays a critical role in the regulation of type I collagen fibril assembly and lateral growth (fibrillogenesis) (Wenstrup et al, 2011). There is an inverse relationship between fibril diameter and type $\mathrm{V}$ collagen content, increased type $\mathrm{V}$ collagen content in the fibril causes thinner fibres. This in turn is believed to alter the mechanical properties of tissues such as the Achilles tendon (Collins \& Posthumus, In Press). Type V collagen is therefore an important structural component of tendons and other connective tissues. In addition, since both copies of the COL5A1 gene are required for normal collagen fibril formation (Wenstrup et al, 2006; Malfait et al, 2010), it is possible that relatively small changes in COL5A1 mRNA stability within the normal physiological range (non-pathological) could result in inter-individual variation in fibrillogenesis, mechanical properties and susceptibility to musculoskeletal soft tissue injuries, as well as, variations in flexibility and endurance running performance (Collins \& Posthumus, In Press).

\subsection{Fibrilogenesis and Achilles injuries}

As described above a variant within the functional $3^{\prime}$-UTR of COL5A1 is associated with chronic Achilles tendinopathy, another musculoskeletal soft tissue injury and other exercise related phenotypes. In addition we have mentioned that type $\mathrm{V}$ collagen is essential for life and is an important protein regulating fibrillogenesis in tendons and other connective tissues. Other proteins besides type $\mathrm{V}$ collagen also regulate fibrillogenesis and therefore the gene encoding these proteins should also be considered ideal candidate genes for chronic Achilles tendinopathy.

Other proteins involved in fibrillogenesis, including type XI, XII and XIV collagens, the proteoglycans, decorin, lumican and fibromodulin, as well as the matricellular protein, thrombospondin 2 (Fichard et al, 1995; Reed \& Iozzo, 2002; Chakravarti, 2002; Bornstein et al, 2000). In addition, like tenascin $C$ which is regulated in tendons by mechanical stress, type XII and type XIV collagens are also expressed in both tendons and ligaments and regulated by mechanical stretch (Chiquet, 1999; Nishiyama et al, 1994). It has also been postulated that type XII and XIV collagens play an important role in the regulation of fibril assembly due to their ability to interact with proteoglycans such as decorin, lumican and fibromodulin (Ezura et al, 2000; Svensson et al, 2000; Danielson et al, 1997). Immunoelectron microscopy has shown that both these collagen types are associated with the surface of collagen fibrils, suggesting that they might possible be able to form interfibrillar connections and mediate fibril interaction with other extracellular and cell surface molecules (Schuppan et al, 1990; Keene et al 1991; Zhang et al, 1993; Walchli et al, 1994). Both type XII and XIV collagens are homotrimers and belong to the sub-family of fibril-associated collagens with interrupted triple helices (FACIT) and are encoded for by the COL12A1 and COL14A1 genes, respectively (Shaw \& Olsen, 1991; Mayne \& Brewton, 1993; Olsen, 1995). Variants within COL12A1 and COL14A1 were however not associated with these injuries (September et al, 2008). Although some of the tested variants were non-synonymous (changed an amino acid in the protein), we cannot exclude the possibility that other untested variants within 
COL12A1 and COL14A1 are associated with Achilles tendinopathy. Interestingly the variants within the COL12A1 gene were however associated with ACL ruptures in females (Posthumus et al, 2010). The association of other genes encoding for proteins involved in fibrillogenesis remains to be tested.

\section{Future research, applied and clinical significance}

Several genetic markers located within genes encoding for tendon structural proteins, extracellular proteinases and signaling molecules have been shown to be associated with chronic Achilles tendinopathy. These results indicate that the genetic contribution for these injuries is polygenic and that several biological pathways are involved. The polygenic natures of Achilles tendon injuries is not surprising, since, as illustrated in figure 1, many of the intrinsic risk factors are determined by both genetic and environmental factors.

Most of the reported associations have been confirmed in a second population (September et al, 2009; Posthumus et al, 2010). The sample sizes of the study population have however generally been small and therefore such studies should be repeated in other populations as well as non-Caucasian populations. The association of these variants should also be tested in Achilles tendon ruptures. Interestingly, the preliminary findings suggest that there might be similarities and differences when identifying genetic elements associated within ruptures and tendinopathy (e.g. Mokone et al, 2005; 2006).

Although human DNA is over 99.9\% identical (Burton et al., 2011), the $0.1 \%$ sequence differences (polymorphisms) partially explains why (i) every athlete is not identical (biological variation), (ii) every athlete's Achilles tendon structure is not identical, (iii) the tendons response to loading is not identical, and (iv) their response to healing (treatment modalities) is not identical. As previously discussed in an editorial (Collins, 2010), these factors fall within the developing disciple of personalized medicine. With this in mind, genetic markers could one day be included in multifactorial models to explain interindividual variation in susceptibility to injury, as well as, response to training, prevention programmes, treatment and rehabilitation. Much more work is however required before this becomes a reality. It is however important to reiterate that Achilles tendon and other musculoskeletal soft tissue injuries are all multifactorial in nature. There is no single factor that causes any of these injuries. The inclusion of genetic markers into any model that has clinical applications could never be used for diagnostic purposes. Their inclusion will only help in determining risk. The inclusion of genetic risk factors in risk models raises ethical issues, which need to be addressed before any clinical service becomes a reality (Collins, 2010; A.G Williams \& Wackerhage, 2009).

Besides the obvious clinical applications, the identification of genetic elements associated with Achilles tendon injuries will compliment the other biological disciplines in understanding and elucidating the biological mechanisms of these injuries. This is a less discussed and appreciated application. It is however currently an important application of this area of research. Some of the previously reported associated genetic markers are functional. It is therefore possible to postulate how these genes, or more specifically their protein products are involved in the etiology of the injuries. These possible mechanism need to be proved or verified using other biological techniques. As previously reviewed (Collins 
\& Posthumus, In Press) work is currently ongoing to explain how variants within the $3^{\prime}$ UTR of the COL5A1 gene could be directly involved in the susceptibility to Achilles tendon injuries. One of the reasons the current risk models (figure 1) have limited practical application in determining risk of injury for a individual athlete is that they are not based on an understanding on the biological mechanisms causing the injury.

We propose that future risk models should be developed around an understanding of the biological mechanisms of Achilles tendon injuries (Figure 2). Current and future research using human molecular genetics and other biological techniques will play an important part in elucidating the mechanisms and developing more appropriate risk models.

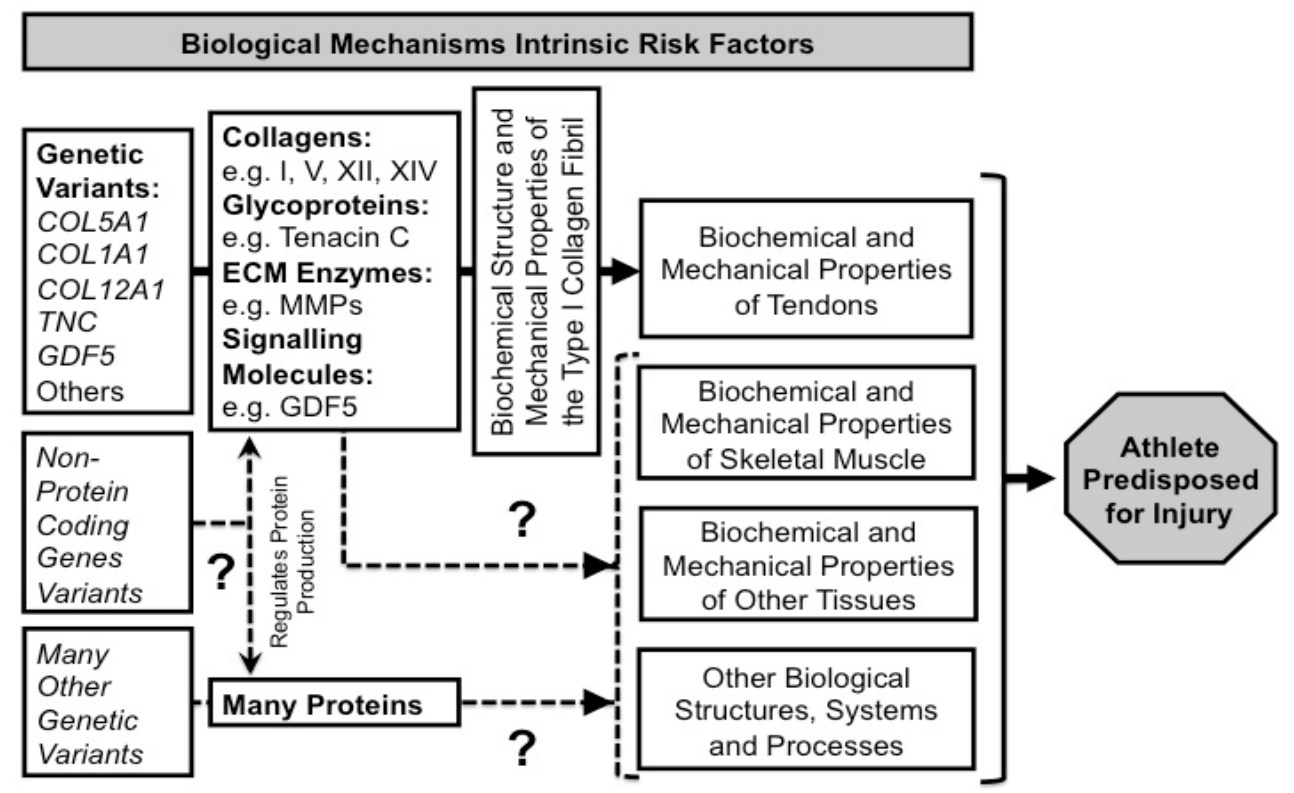

Fig. 2. A schematic illustrating how proposed molecular and biological mechanisms could more accurately describe intrinsic component for Achilles tendon injury risk. In this hypothetical model, inter-individual variations in the biochemical and mechanical properties of the tendon, skeletal muscle and other tissues, as well as, other biological structures, systems and processes cause susceptibility to Achilles tendon injuries. Structural differences and levels of proteins within the tissue cause the inter-individual variations. These differences are in turn partly determined by functional genetic variations within protein-coding and non-coding genes. The predisposed athletes will become a susceptible athlete if exposed to the appropriate extrinsic factors and only become injured (acute injury) or symptomatic (overuse injury) after a specific, usually identifiable, inciting event as illustrated in figure 1.

\section{References}

Alfredson H, Lorentzon, M., Bäckman, S., Bäckman, A., \& Lerner, U. H. (2003). cDNA-arrays and real-time quantitative PCR techniques in the investigation of chronic Achilles 
tendinosis. Journal of orthopaedic research: official publication of the Orthopaedic Research Society, 21(6), 970-975.

Arampatzis A, De Monte, G., Karamanidis, K., Morey-Klapsing, G., Stafilidis, S., \& Brüggemann, G.-P. (2006). Influence of the muscle-tendon unit's mechanical and morphological properties on running economy. The Journal of experimental biology, 209(Pt 17), 3345-3357.

Battie MC LE, Videman T, Burton K, Kaprio J. (2008).Heritability of lumbar flexibility and the role of disc degeneration and body weight. Journal of Applied Physiology, 104: 379-385.

Bornstein P, Armstrong, L. C., Hankenson, K. D., Kyriakides, T. R., \& Yang, Z. (2000). Thrombospondin 2, a matricellular protein with diverse functions. Matrix biology: journal of the International Society for Matrix Biology, 19(7), 557-568.

Brown JC, Miller, C.-J., Schwellnus, M. P., \& Collins, M. (2011a). Range of motion measurements diverge with increasing age for COL5A1 genotypes. Scandinavian Journal of Medicine $\mathcal{E}$ Science in Sports. In press

Brown JC, Miller, C.-J., Posthumus, M., Schwellnus, M. P., \& Collins, M. (2011b). The COL5A1 gene, ultra-marathon running performance and range of motion. An original investigation. International Journal of Sports Physiology and Performance. In Press

Burton PR, Tobin MD Hopper JL (2011). Genetic association studies, In: An introduction to genetic epidemiology, Edited by Palmer LJ, Burton PR and Davey Smith, G, (5-38), The Policy press, ISBN 9781861348975, Bristol, UK

Canty EG, \& Kadler, K. E. (2002). Collagen fibril biosynthesis in tendon: a review and recent insights. Comparative biochemistry and physiology Part A, Molecular $\mathcal{E}$ integrative physiology, 133(4), 979-985.

Chakravarti S. Functions of lumican and fibromodulin: lessons from knockout mice. Glycoconjugate Journal, 19: 287-293, 2002.

Chiquet, M. (1999). Regulation of extracellular matrix gene expression by mechanical stress. Matrix biology : journal of the International Society for Matrix Biology, 18(5), 417-426.

Collins M. (2010). Genetic risk factors for soft-tissue injuries 101: a practical summary to help clinicians understand the role of genetics and 'personalised medicine'. British Journal of Sports Medicine 44: 915-917.

Collins M, and Posthumus M. (2011) Type V Collagen Genotype and Exercise-Related Phenotype Relationships: A Novel Hypothesis. Exercise and Sports Sciences Reviews. In press

Collins M, and Raleigh SM. (2009). Genetic risk factors for musculoskeletal soft tissue injuries. Medicine Sport Science54: 136-149.

Cordell HJ, and Clayton DG (2011). Genetic association studies, In: An introduction to genetic epidemiology, Edited by Palmer LJ, Burton PR and Davey Smith, G, (61-89), The Policy press, ISBN 9781861348975, Bristol, UK

Danielson KG, Baribault, H., Holmes, D. F., Graham, H., Kadler, K. E., \& Iozzo, R. V. (1997). Targeted disruption of decorin leads to abnormal collagen fibril morphology and skin fragility. The Journal of cell biology, 136(3), 729-743. 
de Mos M, Joosten LA, Oppers-Walgreen B, van Schie JT, Jahr H, van Osch GJ, and Verhaar JA. (2009). Tendon degeneration is not mediated by regulation of Toll-like receptors 2 and 4 in human tenocytes. Journal of Orthopaedic Research27: 1043-1047.

Dumke CL, Pfaffenroth, C. M., McBride, J. M., \& McCauley, G. O. (2010). Relationship between muscle strength, power and stiffness and running economy in trained male runners. International journal of sports physiology and performance, 5(2), 249261.

Egli RJ, Southam L, Wilkins JM, Lorenzen I, Pombo-Suarez M, Gonzalez A, Carr A, Chapman K, and Loughlin J. (2009). Functional analysis of the osteoarthritis susceptibility-associated GDF5 regulatory polymorphism. Arthritis \& Rheumatism 60: 2055-2064.

Ezura Y, Chakravarti, S., Oldberg, A., Chervoneva, I., \& Birk, D. E. (2000). Differential expression of lumican and fibromodulin regulate collagen fibrillogenesis in developing mouse tendons. The Journal of cell biology, 151(4), 779-788.

Fichard A, Kleman, J. P., \& Ruggiero, F. (1995). Another look at collagen V and XI molecules. Matrix biology : journal of the International Society for Matrix Biology, 14(7), 515-531.

Fletcher JR, Esau SP, and MacIntosh BR. (2010) Changes in tendon stiffness and running economy in highly trained distance runners. European Journal of Applied Physiology110: 1037-1046.

Grant SF, and Hakonarson H. (2008). Microarray technology and applications in the arena of genome-wide association. Clinical Chemistry54: 1116-1124.

Herrera BM, \& Lindgren, C. M. (2010). The genetics of obesity. Current diabetes reports, 10(6), 498-505.

Hosking FJ, Dobbins SE, and Houlston RS. (2011). Genome-wide association studies for detecting cancer susceptibility. British Medical Bulletin, 97: 27-46.

Hou Y, Mao Z, Wei X, Lin L, Chen L, Wang H, Fu X, Zhang J, and Yu C. (2009). The roles of TGF-beta1 gene transfer on collagen formation during Achilles tendon healing. Biochemical and biophysical research communications, 383: 235-239.

Ireland D, Harrall, R., Curry, V., Holloway, G., Hackney, R., Hazleman, B., \& Riley, G. (2001). Multiple changes in gene expression in chronic human Achilles tendinopathy. Matrix biology : journal of the International Society for Matrix Biology, 20(3), 159-169.

Jelinsky SA, Rodeo SA, Li J, Gulotta LV, Archambault JM, and Seeherman HJ. (2011). Regulation of gene expression in human tendinopathy. BMC Musculoskeletal Disorders 12: 86.

Jones FS, and Jones PL. (2000). The tenascin family of ECM glycoproteins: structure, function, and regulation during embryonic development and tissue remodeling. Developmental Dynamics 218: 235-259.

Jozsa L, Balint JB, Kannus P, Reffy A, and Barzo M. (1989). Distribution of blood groups in patients with tendon rupture. An analysis of 832 cases. The Journal of bone and oint surgery. British volume, 71: 272-274.

Kannus P. (2000). Structure of the tendon connective tissue. Scandinavian journal of medicine $\mathcal{E}$ science in sports, 10: 312-320, 
Kannus P, and Natri A. (1997). Etiology and pathophysiology of tendon ruptures in sports. Scandinavian journal of medicine $\mathcal{E}$ science in sports,7: 107-112.

Keene DR, Lunstrum, G. P., Morris, N. P., Stoddard, D. W., \& Burgeson, R. E. (1991). Two type XII-like collagens localize to the surface of banded collagen fibrils The Journal of cell biology, 113(4), 971-978.

Kousta E, Papathanasiou, A., \& Skordis, N. (2010). Sex determination and disorders of sex development according to the revised nomenclature and classification in 46,XX individuals Hormones (Athens, Greece), 9(3), 218-131.

Kujala UM, Jarvinen M, Natri A, Lehto M, Nelimarkka O, Hurme M, Virta L, and Finne J. (1992). ABO blood groups and musculoskeletal injuries. Injury 23: 131-133,

Laguette M-J, Abrahams, Y., Prince, S., \& Collins, M. (2011). Sequence variants within the 3'UTR of the COL5A1 gene alters mRNA stability: Implications for musculoskeletal soft tissue injuries Matrix biology : journal of the International Society for Matrix Biology, 30(5-6), 338-345.

Leppilahti J, Puranen J, and Orava S. (1996). ABO blood group and Achilles tendon rupture. Annales chirurgiae et gynaecologiae, 85: 369-371.

Lewis CM. (2002). Genetic association studies: design, analysis and interpretation. Briefings in bioinformatics, 3: 146-153.

Maffulli N, Reaper JA, Waterston SW, and Ahya T. (2000). ABO blood groups and achilles tendon rupture in the Grampian Region of Scotland. Clinical journal of sport medicine : official journal of the Canadian Academy of Sport Medicine, 10: 269-271.

Magra M and Maffulli N. (2007). Genetics: Does it play a role in tendinopathy?. Clinical Journal of Sports Medicine 17 (4), 231-233.

Malfait F, Wenstrup, R. J., \& De Paepe, A. (2010). Clinical and genetic aspects of EhlersDanlos syndrome, classic type. Genetics in medicine : official journal of the American College of Medical Genetics, 12(10), 597-605.

Mayne R, and Brewton RG. (1993). New members of the collagen superfamily. Current opinion in cell biology, 5: 883-890.

Mazumder B, Seshadri, V., \& Fox, P. L. (2003). Translational control by the 3'-UTR: the ends specify the means. Trends in Biochemical Sciences, 28(2), 91-98.

Meeuwisse WH. (1994). Assessing causation in sport injury: a multifactorial model. Clinical journal of sport medicine : official journal of the Canadian Academy of Sport Medicine, 4:166-170.

Mokone GG, Schwellnus, M. P., Noakes, T. D., \& Collins, M. (2006). The COL5A1 gene and Achilles tendon pathology. Scandinavian Journal of Medicine $\mathcal{E}$ Science in Sports, 16(1), 19-26.

Mokone GG, Gajjar, M., September, A. V., Schwellnus, M. P., Greenberg, J., Noakes, T. D., \& Collins, M. (2005). The guanine-thymine dinucleotide repeat polymorphism within the tenascin-C gene is associated with achilles tendon injuries. The American Journal of Sports Medicine, 33(7), 1016-1021.

Newman AB, Walter, S., Lunetta, K. L., Garcia, M. E., Slagboom, P. E., Christensen, K., Arnold, A. M., et al. (2010). A meta-analysis of four genome-wide association studies of survival to age 90 years or older: the Cohorts for Heart and Aging 
Research in Genomic Epidemiology Consortium The journals of gerontology Series A, Biological sciences and medical sciences, 65(5), 478-487.

Nishiyama T, McDonough AM, Bruns RR, and Burgeson RE. (1994). Type XII and XIV collagens mediate interactions between banded collagen fibers in vitro and may modulate extracellular matrix deformability. The Journal of Biological Chemistry, 269: 28193-28199

Olsen BR. (1995). New insights into the function of collagens from genetic analysis. Current opinion in cell biology 7: 720-727.

Posthumus M, September, A. V., O'cuinneagain, D., van der Merwe, W., Schwellnus, M. P., \& Collins, M. (2009). The COL5A1 gene is associated with increased risk of anterior cruciate ligament ruptures in female participants. The American Journal of Sports Medicine, 37(11), 2234-2240.

Posthumus M, Schwellnus, M. P., \& Collins, M. (2011). The COL5A1 gene: a novel marker of endurance running performance. Medicine and science in sports and exercise, 43(4), 584-589.

Posthumus M, September, A. V., O'cuinneagain, D., van der Merwe, W., Schwellnus, M. P., \& Collins, M. (2010). The association between the COL12A1 gene and anterior cruciate ligament ruptures. British Journal of Sports Medicine, 44(16), 1160-1165.

Posthumus M, Collins M, Cook J, Handley CJ, Ribbans WJ, Smith RK, Schwellnus MP, and Raleigh SM. (2010). Components of the transforming growth factor-beta family and the pathogenesis of human Achilles tendon pathology--a genetic association study. Rheumatology (Oxford) 49: 2090-2097.

Puddu G, Ippolito, E., \& Postacchini, F. (1976). A classification of Achilles tendon disease. The American Journal of Sports Medicine, 4(4), 145-150.

Raleigh SM, van der Merwe L, Ribbans WJ, Smith RK, Schwellnus MP, and Collins M. (2009). Variants within the MMP3 gene are associated with Achilles tendinopathy: possible interaction with the COL5A1 gene. British Journal of Sports Medicine 43: 514520 ,

Reed CC, \& Iozzo, R. V. (2002). The role of decorin in collagen fibrillogenesis and skin homeostasis. Glycoconjugate journal, 19(4-5), 249-255.

Riley, G. (2004). The pathogenesis of tendinopathy. A molecular perspective. Rheumatology (Oxford, England), 43(2), 131-142.

Schuppan D, Cantaluppi, M. C., Becker, J., Veit, A., Bunte, T., Troyer, D., Schuppan, F., et al. (1990). Undulin, an extracellular matrix glycoprotein associated with collagen fibrils. The Journal of biological chemistry, 265(15), 8823-8832.

September AV, Cook, J., Handley, C. J., Van Der Merwe, L., Schwellnus, M. P., \& Collins, M. (2009). Variants within the COL5A1 gene are associated with Achilles tendinopathy in two populations. British Journal of Sports Medicine, 43(5), 357-365.

September AV, Mokone, G. G., Schwellnus, M. P., \& Collins, M. (2006). Genetic risk factors for Achilles tendon injuries. International SportMed Journal, 7(3), 201-215.

September AV, Posthumus, M., Van Der Merwe, L., Schwellnus, M. P., Noakes, T. D., \& Collins, M. (2008). The COL12A1 and COL14A1 genes and Achilles tendon injuries. International journal of sports medicine, 29(3), 257-263. 
September AV, Schwellnus, M. P., \& Collins, M. (2007). Tendon and ligament injuries: the genetic component. British Journal of Sports Medicine, 41(4), 241-246.

September AV, Nell EM, O'Connell K, Cook J, Handley CJ, van der Merwe L, Schwellnus M, and Collins M. (2011). A pathway-based approach investigating the genes encoding interleukin-1\{beta\}, interleukin-6 and the interleukin-1 receptor antagonist provides new insight into the genetic susceptibility of Achilles tendinopathy. British Journal of Sports Medicine. In Press

Shaw LM, and Olsen BR. (1991). FACIT collagens: diverse molecular bridges in extracellular matrices. Trends in Biochemical Sciences, 16: 191-194.

Silver FH, Freeman, J. W., \& Seehra, G. P. (2003). Collagen self-assembly and the development of tendon mechanical properties. Journal of Biomechanics, 36(10), 1529_ 1553.

Stewart CEH, \& Rittweger, J. (2006). Adaptive processes in skeletal muscle: molecular regulators and genetic influences. Journal of musculoskeletal $\mathcal{E}$ neuronal interactions, 6(1), 73-86.

Svensson L, Närlid, I., \& Oldberg, A. (2000). Fibromodulin and lumican bind to the same region on collagen type I fibrils. FEBS letters, 470(2), 178-182.

Valdes AM, Evangelou E, Kerkhof HJ, Tamm A, Doherty SA, Kisand K, Kerna I, Uitterlinden A, Hofman A, Rivadeneira F, Cooper C, Dennison EM, Zhang W, Muir KR, Ioannidis JP, Wheeler M, Maciewicz RA, van Meurs JB, Arden NK, Spector TD, and Doherty M. (2011) The GDF5 rs143383 polymorphism is associated with osteoarthritis of the knee with genome-wide statistical significance. Annals of the rheumatic diseases, 70: 873-875.

Wälchli C, Koch, M., Chiquet, M., Odermatt, B. F., \& Trueb, B. (1994). Tissue-specific expression of the fibril-associated collagens XII and XIV. Journal of Cell Science, 107 ( Pt 2), 669-681.

Wenstrup RJ, Smith, S. M., Florer, J. B., Zhang, G., Beason, D. P., Seegmiller, R. E., Soslowsky, L. J and Birk DE. (2011). Regulation of collagen fibril nucleation and initial fibril assembly involves coordinate interactions with collagens V and XI In developing tendon. The Journal of Biological Chemistry, 286, 20455-20465

Wenstrup RJ, Florer, J. B., Davidson, J. M., Phillips, C. L., Pfeiffer, B. J., Menezes, D. W., Chervoneva, I and Birk DE. (2006). Murine model of the Ehlers-Danlos syndrome. col5a1 haploinsufficiency disrupts collagen fibril assembly at multiple stages. The Journal of biological chemistry, 281(18), 12888-12895.

Williams AG, and Wackerhage H. Genetic testing of athletes. Medicine Sport Science, 54: 176186, 2009.

Williams FM, Popham M, Hart DJ, de Schepper E, Bierma-Zeinstra S, Hofman A, Uitterlinden AG, Arden NK, Cooper C, Spector TD, Valdes AM, and van Meurs J. (2011). GDF5 single-nucleotide polymorphism rs143383 is associated with lumbar disc degeneration in Northern European women. Arthritis and rheumatism, 63: 708712 .

Young JS, Kumta SM, and Maffulli N. (2005) Achilles tendon rupture and tendinopathy: management of complications. Foot and ankle clinics, 10: 371-382. 
Zhang X, Schuppan D, Becker J, Reichart P, and Gelderblom HR. (1993). Distribution of undulin, tenascin, and fibronectin in the human periodontal ligament and cementum: comparative immunoelectron microscopy with ultra-thin cryosections. The journal of histochemistry and cytochemistry: official journal of the Histochemistry Society 41: 245-251. 


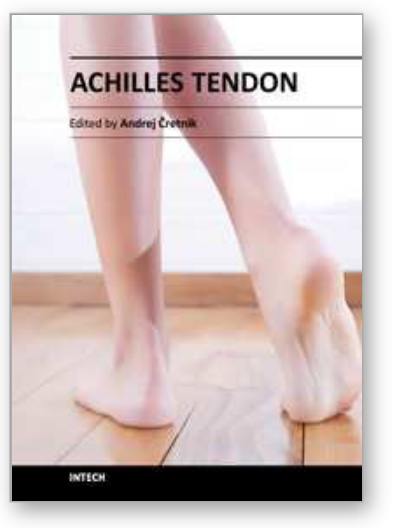

\author{
Achilles Tendon \\ Edited by Prof. Andrej Cretnik
}

ISBN 978-953-51-0264-9

Hard cover, 144 pages

Publisher InTech

Published online 08, January, 2012

Published in print edition January, 2012

Achilles tendon has always attracted a great attention. Its disorders include various problems from pain and swelling with bumps to functional impairment or even ruptures. Debates concerning aetiology and optimal treatment are still going on. A lot of efforts and research have already been put on to find the answers to unsolved problems and this book is an attempt to share (some of) these findings to the readers. If only one of the papers helps the therapists or patients in understanding and solving their problems, we will consider that the mission of the book was accomplished.

\title{
How to reference
}

In order to correctly reference this scholarly work, feel free to copy and paste the following:

Stuart M. Raleigh and Malcolm Collins (2012). Gene Variants that Predispose to Achilles Tendon Injuries: An Update on Recent Advances, Achilles Tendon, Prof. Andrej Cretnik (Ed.), ISBN: 978-953-51-0264-9, InTech, Available from: http:/www.intechopen.com/books/achilles-tendon/gene-variants-that-predispose-to-achillestendon-injuries-an-update-on-recent-advances-

\section{INTECH}

open science / open minds

\section{InTech Europe}

University Campus STeP Ri

Slavka Krautzeka 83/A

51000 Rijeka, Croatia

Phone: +385 (51) 770447

Fax: +385 (51) 686166

www.intechopen.com

\section{InTech China}

Unit 405, Office Block, Hotel Equatorial Shanghai

No.65, Yan An Road (West), Shanghai, 200040, China

中国上海市延安西路65号上海国际贵都大饭店办公楼405单元

Phone: +86-21-62489820

Fax: +86-21-62489821 
(C) 2012 The Author(s). Licensee IntechOpen. This is an open access article distributed under the terms of the Creative Commons Attribution 3.0 License, which permits unrestricted use, distribution, and reproduction in any medium, provided the original work is properly cited. 